\title{
TARP syndrome
}

INSERM

\section{Source}

INSERM. (1999). Orphanet: an online rare disease and orphan drug data base. TARP syndrome. ORPHA:2886

TARP syndrome is a rare developmental defect during embryogenesis syndrome characterized by Robin sequence (micrognathia, glossoptosis, and cleft palate), atrial septal defect, persistence of the left superior vena cava, and talipes equinovarus. The phenotype is variable, some patients present with further dysmorphic characteristics (e.g. hypertelorism, ear abnormalities) while others do not have any key findings. Additional features, such as syndactyly, polydactyly, or brain anomalies (e.g. cerebellar hypoplasia), have also been reported. The syndrome is almost invariably lethal with affected males either dying prenatally or living just a few months. 